\title{
Alterations of IL-1 and VEGF After Ischemia-Reperfusion Injured Uterus and Ovary in Rats
}

\author{
İskemi/Reperfüzyon Hasarı Sonrası Sıçanların Over ve Uterusunda IL-1 \\ ve VEGF Değişiklikleri
}

\section{Yasemin ERSOY CANILLIOGLU $\odot$, Gozde ERKANLI SENTURK $\odot$}

\author{
*These authors contribute equally to the study. \\ Ethics Committee Approval: This study was approved by the Yeditepe University Ethical Committee \\ of Animal Care, 1 August 2019, 2019/772. \\ Conflict of interest: The authors declare that they have no conflict of interest. \\ Funding: None. \\ Informed Consent: Not Applicable.
}

Cite as: Ersoy Canillioglu Y, Erkanli Senturk G. Alterations of IL-1 and VEGF after ischemiareperfusion injured uterus and ovary in rats. Medeniyet Med J. 2020;35:106-15.

\begin{abstract}
Objective: Ischemia/reperfusion injury causes parenchymal and endothelial cell damage as a result of inflammation. Vascular endothelial growth factor (VEGF) expressed in every kind of tissue in human body has important roles in migration, proliferation, endothelial cell permeability, angiogenesis and vasculogenesis. IL-1 is a one of the cytokine family members, and plays important roles in hematopoiesis, inflammatory reactions and immune system regulation. Furthermore, auto-inflammatory diseases are treated by IL-1 as therapeutic agent. The aim of this study is to observe changes of VEGF and IL-1 immunreactivity in ischemia/reperfused rat uterus and ovary.

Method: Rats were separated into two groups. Control group and ischemia/reperfusion group which rats were subjected to $45 \mathrm{~min}$ ischemia/45 min reperfusion. Samples from uterus and ovary were fixed with $10 \%$ neutral formaldehyde and stained with H\&E. VEGF and IL-1 immunohistochemistry was applied.

Results: Histopathological results showed severe degeneration of endometrium in uterus and ovarian follicles in ischemia/reperfusion group. VEGF and IL-1 immunoreactivity increased in uteruses and ovaries of ischemia/reperfusion group when compared to control group Conclusion: In consequence, the present results suggest that VEGF and IL-1 may be potential detection marker for ischemia/reperfusion injured uterus and ovary. Moreover, VEGF and IL-1 might be in relation with each other to regenerate uterus and ovary.
\end{abstract}

Keywords: IL-1,VEGF, ischemia, reperfusion, uterus, ovary, rat

öz

Amaç: İskemi/reperfüzyon hasarından dolayı oluşan inflamasyon parenkimal ve endotelyal hücre hasarına neden olmaktadır. Vücuttaki her tip hücreden eksprese edilen Vaskuler Endotelyal Büyüme Faktörü (VEGF), anjiyogenez ve vaskülogenezde, endotelyal hücre geçirgenliğinde, çoğalma ve migrasyonda çok önemli bir role sahiptir. Sitokin ailesinin bir üyesi olan IL-1, hematopoiezde, inflamasyon reaksiyonlarında ve immün sistem regulasyonunda önemli bir role sahiptir. Ayrıca, inflamatuvar hastalıklar terapatik ajan olan IL-1 ile tedavi edilmektedir. Bu çalışmanın amacl, Iskemi/reperfüzyon yapılmış sıçanların over ve uterusunda VEGF ve IL-1 immunreaktivitesinde ki değişiklikleri araştırmaktır.

Yöntem: Sıçanlar iki gruba ayrılmıștır. Kontrol grubu ve 45dk iskemi/45 dk reperfüzyon yapılmıș İskemi/reperfüzyon grubudur. Over ve uterus dokuları \%10'ık nötral formaldehit ile tespit edilmiş ve H\&E ile boyanmıştır. VEGF ve IL-1 immunohistokimyası uygulanmıştır.

Bulgular: Histopatolojik sonuçlar, İskemi/reperfüzyon grubunda uterus endometriyumunda ve over foliküllerinde ciddi derecede hasar göstermiștir. Uterus ve over dokusunda VEGF ve IL-1 immunreaktivitesi iskemi/reperfüzyon grubunda kontrol grubuna oranla artmış bulunmuştur. Sonuc: Bu bulgular over ve uterus dokusunda iskemi/reperfüzyon hasarında VEGF ve IL-1 potansiyel bir marker olarak kullanılabilir. Ayrıca, uterus ve over dokusu rejenerasyonunda VEGF ve IL-1 birbirleriyle etkileşim içerisinde olabilir.

Anahtar kelimeler: IL-1, VEGF, iskemi, reperfüzyon, uterus, over, sıçan
Received: 3 March 2020

Accepted: 10 May 2020

Online First: 30 June 2020

Corresponding Author: G. Erkanli Senturk ORCID: 0000-0002-8235-4157 Istanbul University-Cerrahpasa, Cerrahpaşa Medical Faculty, Department of Histology and Embryology, Istanbul, Turkey

gozdeerkanli@yahoo.com

Y. Ersoy Canillioglu

ORCID: 0000-0002-3839-6931

Bahcesehir University,

School of Medicine,

Department of Histology and Embryology, Istanbul, Turkey 


\section{INTRODUCTION}

Ovarian torsion, also termed as adnexal torsion, is a clinical emergency with a prevalence of $2.7 \%$ in general population. Pregnancies, ovarian cysts, excessive mobility of adnexa are some factors causing ovarian torsion. Because of nonspecific clinical symptoms, diagnosis is often delayed ${ }^{1}$. Ovarian torsion leads to ischemia and necrosis of ovary which requires an immediate treatment such as detorsion, laparoscopy or laparotomy. However, treatment of ovarian torsion by detorsion gives rise to ischemia reperfusion (I/R) injury ${ }^{2}$.

Ischemic injury occurs when there is lack of blood flow to a tissue. Oxygen deprivation is followed by a switch to anaerobic metabolism which fails to fulfill the demands of tissues. Series of chemical reactions result in accumulation of lactic acid, protons, products of glycolysis, and creatine leading to acidosis and inhibition of glycolytic enzymes. Changes in plasma membrane cause electrolyte imbalance, edema and calcium overload which accompany mitochondrial dysfunction and irreversible damage. Since I/R initiates cascades of necrosis and apoptosis, mitochondrial dysfunction is very critical in I/R. Although reperfusion, reestablishment of blood flow, is essential for energy supply and removal of toxic substances, it has serious metabolic consequences ${ }^{3,4}$. I/R injury leads to endothelial and parenchymal cell injury as a result of reactions starting with macrophage activation. Release of cytokines after macrophage activation triggers leukocyte activation. Leukocytes in extravascular space induce release of reactive oxygen species (ROS) ${ }^{5}$. ROS, including singlet oxygen $\left(1 \mathrm{O}_{2}\right)$, superoxide anion radical $\left(\mathrm{O}_{2}^{-}\right)$, hydroxyl radical $(\mathrm{OH}-)$, hydrogen peroxide $\left(\mathrm{H}_{2} \mathrm{O}_{2}\right)$, and nitric oxide (NO-), react with the polyunsaturated fatty acids of membrane lipids and cause membrane rupture, consequently cell death $^{6}$.

Vascular endothelial growth factor (VEGF) expressed in every kind of tissue in human body has important roles in migration, proliferation, endothelial cell permeability, angiogenesis, vasculogenesis, invasion into the basement membrane, and formation of fenestrations. Expression of VEGF, most potent promoter of angiogenesis ${ }^{7}$, is essential in some conditions, such as female reproductive cycle, response of skeletal muscle to exercise and wound healing. Pro-angiogenic therapy using VEGF is also considered in some ischemic diseases such as myocardial ischemia, stroke and wound or fracture healing, and also in Alzheimer's disease ${ }^{8}$.

Ligands and receptors of Interleukin-1 family are associated with chronic and acute inflammation. IL- $1 \beta$, which is one of the 11 members of IL-1 family, is used as a therapeutic for the treatment of auto inflammatory diseases. Mesenchymal stem cells such as endothelial and epithelial cells of lung, kidney, contain preformed IL- $1 \alpha$ precursors. During an ischemic injury, cell membrane integrity is disrupted, resulting in release of cellular contents including IL- $1 \alpha$ precursors. Ischemia- induced inflammation is initially related with IL- $1 \alpha$, but immediately becomes dependent on caspase- 1 and IL- $1 \beta$ as well. This condition can be followed by caspase- 1 related cell death ${ }^{9}$.

In this study; alterations of IL- $1 \alpha$, which is primarily affected in inflammatory response, and VEGF, which plays an important role in angiogenesis and vasculogenesis, in ischemia-reperfused ovary and uterus in rats are investigated and correlation between them is evaluated.

\section{MATERIAL and METHODS}

\section{Animals}

This study was performed according to institutional guidelines with 12 two-month-old female adult Wistar-Albino rats that were in estrous cycle and weighing approximately $200 \mathrm{~g}$. Animals were housed in humidity $(60 \pm 5 \%)$ and temperature $\left(22 \pm 2^{\circ} \mathrm{C}\right)$ controlled quiet rooms where a $12 / 12$ 
h light/dark cycle was provided. All experiments were performed between 9am and 5pm according to the guidelines for animal research and were approved by the Yeditepe University Ethical Committee of Animal Care, Istanbul, Turkey.

\section{Ischemia/Reperfusion Procedure}

Before surgical operations $7 \mathrm{mg} / \mathrm{kg}$ xylazine and $50 \mathrm{mg} / \mathrm{kg}$ ketamine were injected intraperitoneally. Any venous cannula was not used, and all animals spontaneously breathed the room air during surgical procedures. Intravenous heparin was injected 10 min to all animals before induction of ischemia to prevent thrombosis in the occluded artery.

Ischemia/reperfusion injury was induced according to the protocol used in our previous study ${ }^{1}$. The region just above the bifurcation point of abdominal aorta was exposed to Ischemia/Reperfusion (I/R, n:6). In the control group (n:6), the abdominal aorta was not occluded. Blood-flow of the abdominal aorta is controlled by palpation of pulse and visual assessment of color changes of the sole of the foot. The uterus and ovary were rendered ischemic for $90 \mathrm{~min}$, reperfusion for 90 min was achieved by releasing the clamp, and was confirmed by restoration of the pulsatile blood flow in the aorta and disappearance of color change of the sole ${ }^{1}$.

\section{Histopathologic Procedure}

The ovarian and uterine tissue samples obtained were placed in the $10 \%$ buffered formalin solution at $4{ }^{\circ} \mathrm{C}$ and then rinsed under tap water for 2 h. Afterward, the ovarian and uterine tissue samples were dehydrated with successive series of alcohol and cleared with toluene. After overnight incubation, tissues were embedded in paraffin blocks. Sections were cut at $5 \mu \mathrm{m}$ thickness from ovarian and uterine tissue blocks. The samples were stained with hematoxylin and eosin (H\&E) dye. The ovarian tissue samples of each rat were examined and photographed using a microscope Olympus BX53 (Japan). Two blinded observers evaluated the sections according to the following criteria ${ }^{1}$.

For ovaries; each slide was evaluated according to the vascular congestion; edema; follicle degeneration, and inflammatory cell infiltration.

For uterus; each slide was evaluated according to the morphology of endometrial lining and glandular epithelium; cellular structures of myometrium.

\section{Immunohistochemical Procedure of VEGF and IL-1 $\alpha$}

Three to $5 \mu \mathrm{m}$-thick paraffin sections taken from ovary and uterus were put into positively charged slides, and incubated in $42^{\circ} \mathrm{C}$ overnight, deparaffinized with xylene for $30 \mathrm{~min}$, rehydrated with an ethanol series, and washed with distilled water. Slides were incubated with $3 \% \mathrm{H}_{2} \mathrm{O}_{2}$ for 10 min. For antigen retrieval, deparaffinized sections in citrate buffer were brought to boiling temperature in a microwave oven on high power, and then kept boiling for $20 \mathrm{~min}$ at low power. Then they were rinsed with distilled water.

Sections were surrounded with a PAP pen (Pappen, DAKO) and washed with phosphate-buffered saline (PBS). Sections were incubated with blocking solution (Scy Tek, SHP-IFU, USA) for 5 minutes. Then, the sections cut from samples of ovary and uterus were incubated with primary anti-VEGF (1:100; Santa Cruz, sc65617 mouse monoclonal) and primary anti-IL-1 $\alpha$ (1:50, Santa Cruz, sc271618 mouse monoclonal) overnight at $+4^{\circ} \mathrm{C}$. Next, sections were biotinylated with goat anti-mouse antibodies. Afterwards, slides were washed in PBS, the streptavidin peroxidase label reagent (Scy Tek HRP) was applied in a humidity chamber at room temperature for $\mathbf{2 0}$ minutes. The colored product was developed by incubation with DAB chromogen. The slides were counterstained with Mayer's haematoxylin, and all slides were closed by Entellan ${ }^{\circledR}$ after the dehydration procedure $^{10}$. 
VEGF reactions and IL- $1 \alpha$ reactions in ovary and in uterus were observed under light microscopy and digital photographs (Olympus BX53, Japan) were taken Experimental groups were evaluated under light microscopy by a blinded observer. Every fifth section was collected, and in each section, VEGF-immunoreactivity (ir) and IL- $1 \alpha$ - ir were evaluated at $400 \times$ magnification in five randomly selected similar areas. Intensity of staining was scored as none, weak, dense, and intense $(0,+1$, $+2,+3)$ respectively per unit area, and HSCOREs were calculated in consideration of the previous data $^{11}$.

\section{Statistical Analyses}

Statistical analysis was done by using ANOVA and
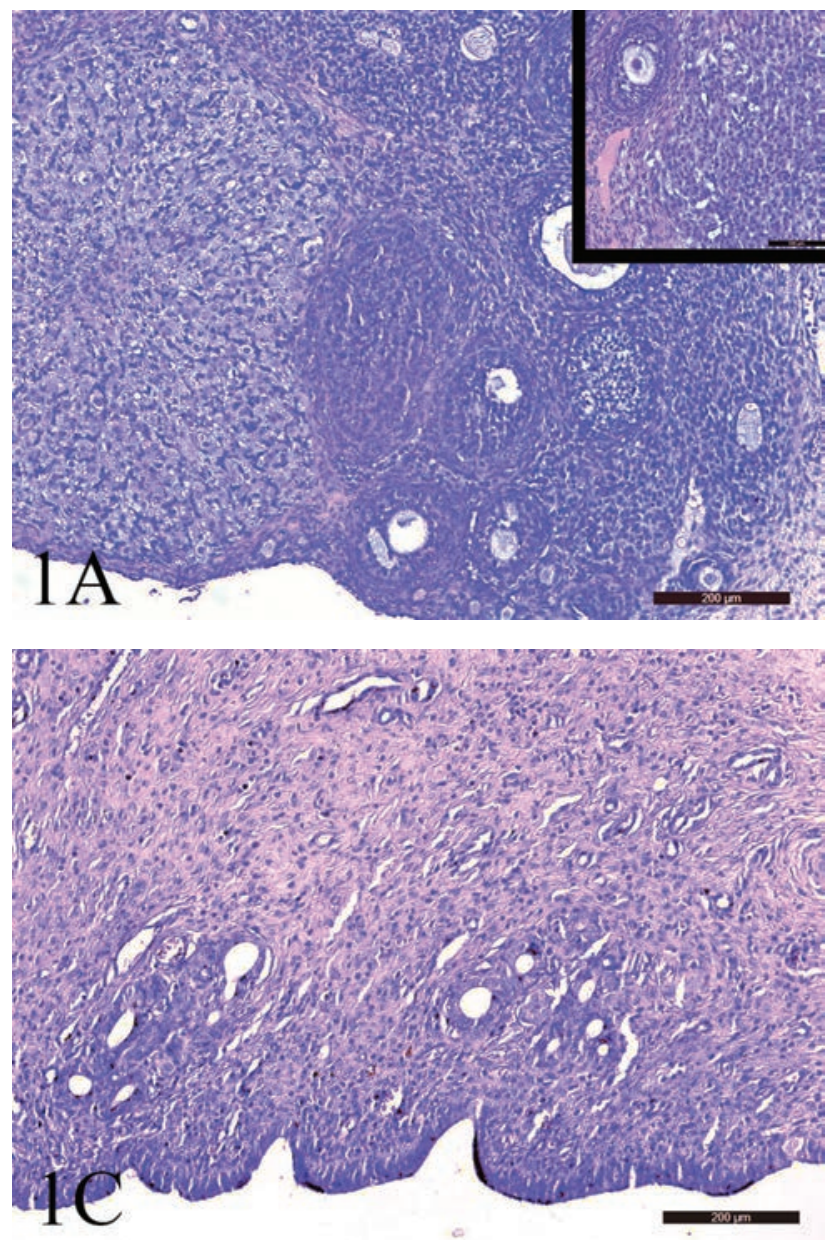

followed with Tukey's multiple comparison tests in Graph Pad Prism 3.0 (Graph Pad Software, San Diego, CA, USA) program. All data was calculated as mean \pm S.D, and $p<0.05$ is considered as significant.

\section{RESULTS}

\section{Histopathological Evaluation}

Histopathological evaluation of the ovaries was done in the control and I/R groups. The medulla and cortex of the ovaries in the control groups were structurally normal. There were different types of follicles with oocytes. Normal stromal, follicular and granular cells were seen in the ovarian tissue of the control group (Figure 1A).
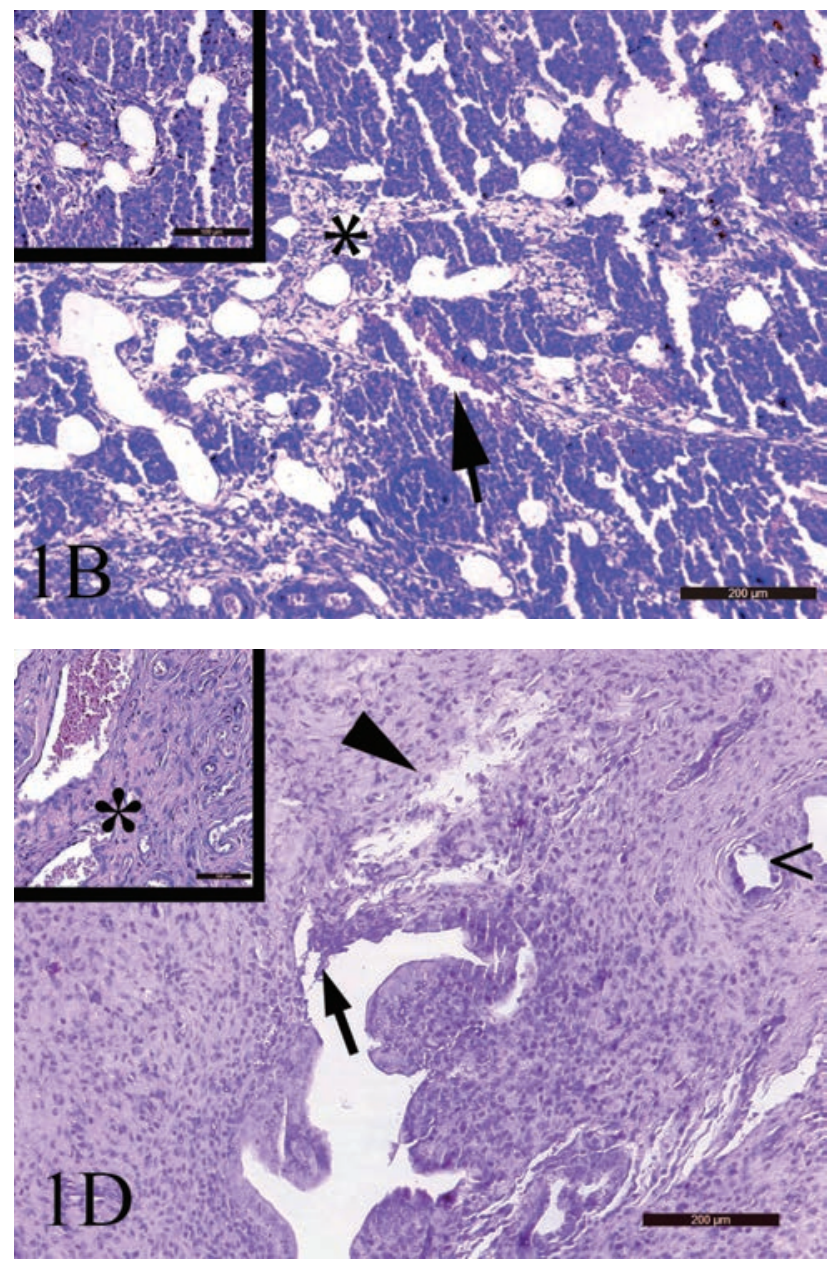

Figure 1. The normal structure of the ovaries in the control groups (A). Normal endometrial morphology with normal luminal and glandular epithelium in uterus of the control group (C). Edema $(*)$, diffuse vascular congestion $(\rightarrow)$ in the ovarian tissue of the I/R group (B). Damaged surface epithelial layer $(\rightarrow)$ and disrupted glandular epithelial cells $(>)$, degenerated stromal area $(\triangleright)$, vascular congestion in myometrium (inset *) of uterus of the I/R group (D). H\&E Stainning. 

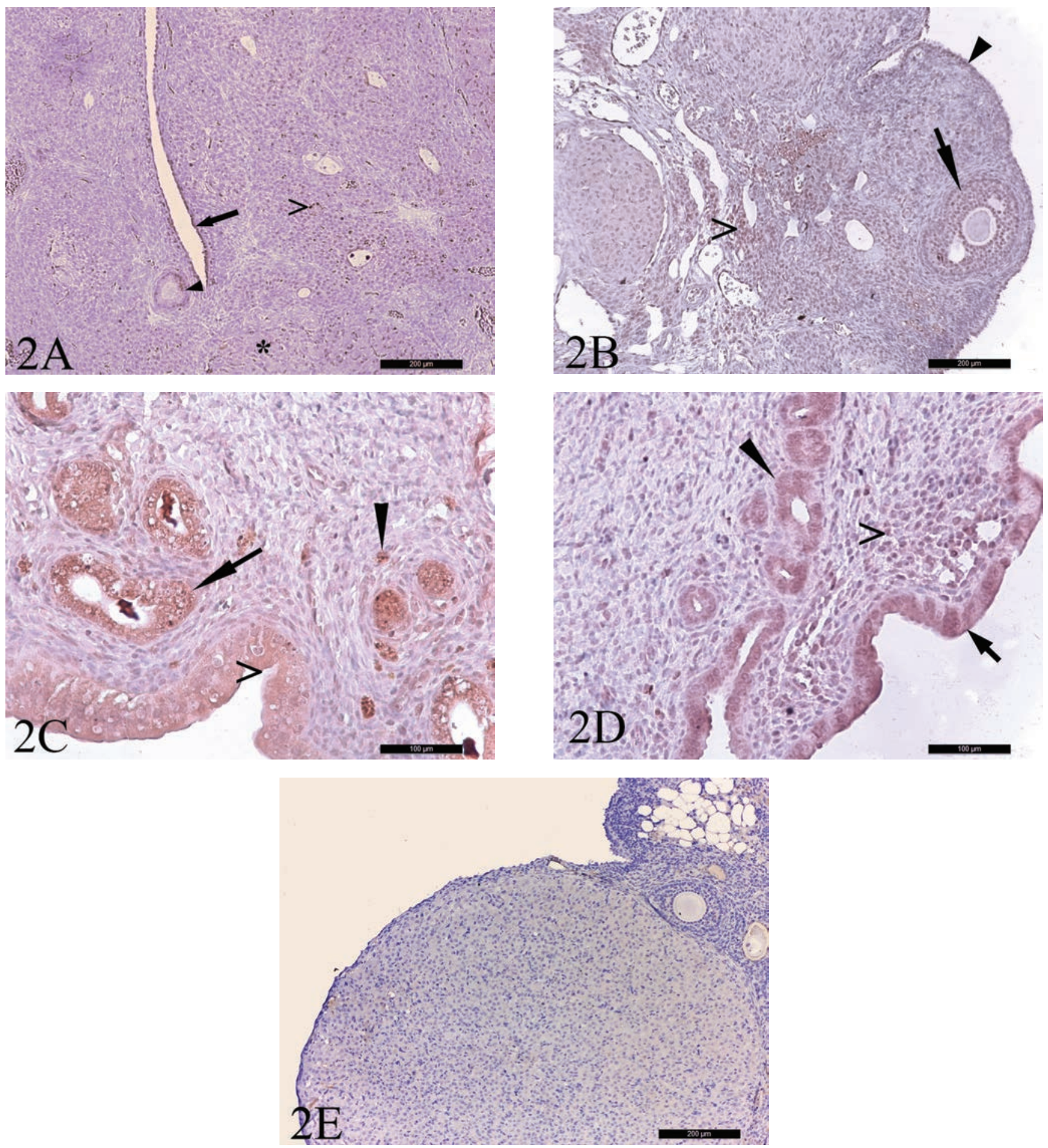

Figure 2. VEGF immunoreactivity: VEGF-ir in granulosa cells $(>)$, germinal epithelium $(\rightarrow)$, stromal cells $(>)$ and luteal granulosa cells $\left(^{*}\right)$ of the ovary in control group $(A)$. Increased VEGF-ir in granulosa cells $(\rightarrow)$, stromal cells $(>)$, germinal epithelium $(\triangleright)$ of the ovary in the I/R group (B). VEGF-ir in endometrial lining epithelial cells $(>)$ uterine glandular epithelial cells $(\rightarrow)$ and stromal cells $(\triangleright)$ of the uterine control group (C). Increased VEG-ir in endometrial lining epithelial cells $(\rightarrow)$, uterine glandular epithelial cells $(>)$ and stromal cells $(>)$ of the uterus in the I/R group (D). Negative staining for VEGF in the ovary tissue (E). 

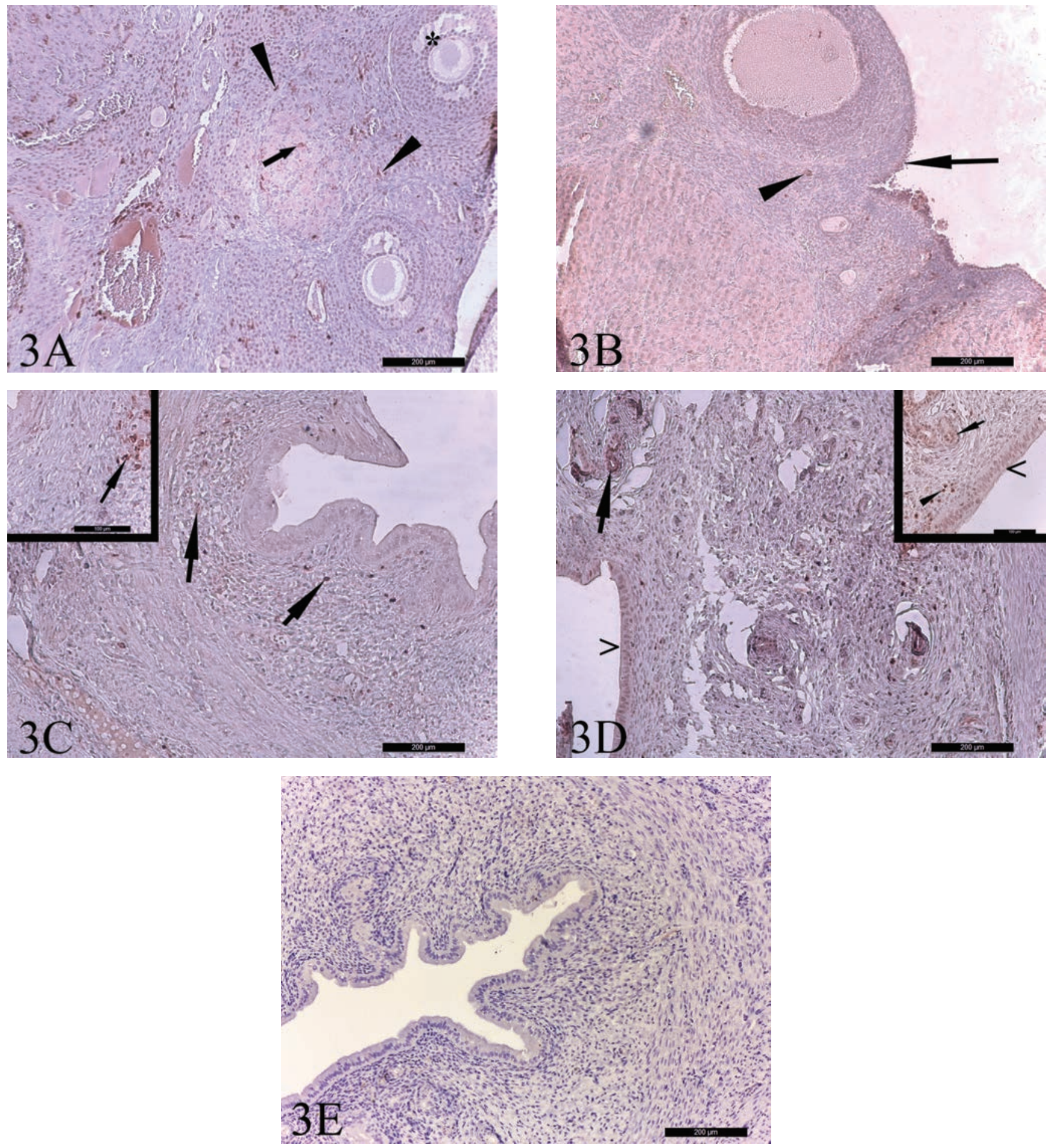

Figure 3. IL-1 $\alpha$ immunoreactivity: IL-1 $\alpha$ immunoreactivity in stromal cells $(\rightarrow)$ and luteal granulosa cells $(\rightarrow)$, cumulus cells $\left({ }^{*}\right)$ of the seconder follicle in the ovary of control group (A). Stronger IL-1 $\alpha$ immunoreactivity in surface epithelial cells $(\rightarrow)$ and in the stromal cells $(>)$ of the ovary in the I/R group (B). IL-1 $\alpha$ immunoreactivity in the glandular epithelial cells (inset $\rightarrow$ ) and the stromal cells $(\rightarrow)$ of the uterus in the control group (C). Stronger IL1 $\alpha$ - ir in the endometrial lining epithelial cells $(>)$ glandular epithelial cells $(\rightarrow)$, and stromal cells (inset $\rightarrow$ ) of the uterus in the I/R group (D). Negative staining for IL- $1 \alpha$ in the uterus tissue (E). 
Severe degeneration of ovarian tissue was observed in I/R groups. Widespread edema, acute inflammatory cell infiltration was located in between stromal cells with diffuse vascular congestion in the I/R group ovaries. Also, different stages of follicle degeneration with granular cells were noted in the ovarian tissue of the I/R group (Figure 1B).

Endometrial areas were examined as normal morphology with luminal and glandular epithelium. Well-preserved cellular structures of the myometrium in uteri of the control group are shown in Figure $1 \mathrm{C}$.

In the uterus tissue of I/R group, slightly damaged surface epithelial cells and disrupted glandular epithelial cells were observed. Increased stromal cell degeneration was detected. There was also vasocongestion in the endometrium and myometrium in the I/R group (Figure 1D).

\section{Immunohistochemistry Evaluation of VEGF and IL-1 $\alpha$}

Brown-colored VEGF immunoreactivity (ir) was detected in the smaller number of stromal, granulosa lutein cells and germinal epithelium in the ovarian tissue samples of the control groups. There was no or weak VEGF-ir positivity in follicular cells of Graafian follicle. Weak VEGF-ir positivity was seen in granulosa cells of primary follicle (Figure 2A). VEGF-ir was detected in endometrial epithelial, glandular and stromal cells of the uterus in the control group (Figure 2C).

VEGF immunostaining was most intensely observed in the I/R group when compared to the control groups (Figure 2B). VEGF-ir was increased in endometrial lining and glandular epithelial cells as well as stromal cells in the I/R group uterus (Figure 2D).

Brown-colored IL $1 \alpha$-ir was detected in germinal epithelial cells and walls of blood vessels and granulosa cells of the ovary in the control group.
Weak IL $1 \alpha$-ir positivity was only located at the theca interna cells. There was no IL $1 \alpha$-ir positivity in theca externa cells (Figure 3A).

IL $1 \alpha$-ir was observed less intensely in the endometrial lining and glandular epithelium as well as myometrial cells of the uterus in the control group (Figure 3C).

IL $1 \alpha$-ir was more intense in germinal epithelial cells, endothelial cells in blood vessels and granulosa cells of the ovary in the I/R group when compared to the control group (Figure 3B). IL $1 \alpha-$-ir was more intense in endometrial lining and glandular epithelial cells and myometrial cells in the uterus of the I/R group compared to the control group (Figure 3D).

Statistical analyses showed that VEGF-ir was increased statistically significantly in the control group when compared to the I/R group $(p<0.05)$ (Table 1, 3). On the other hand, IL1-ir was increased in the control group when compared to the I/R group $(p<0.05)$ (Table 2,3$)$. Besides, increment of VEGF-ir was numerically more than IL1-ir in both ovary and uterus tissues.

Table 1. Distribution of VEGF-ir in ovary and uterus in $I / R$ and control groups.

VEGF Immunohistochemistry Results

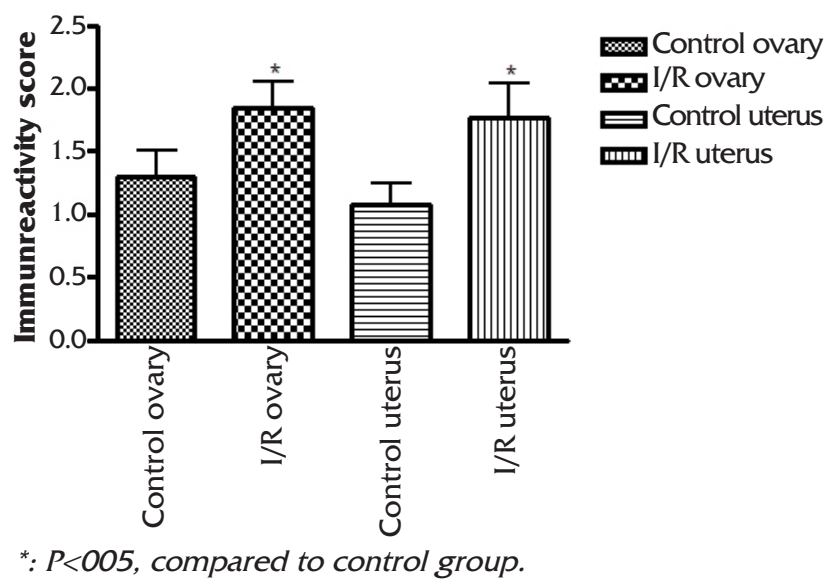


Table 2. Distribution of IL $1 \alpha$-ir in ovary and uterus organs in $\mathbf{I} / \mathbf{R}$ and control groups.

IL-1 Immunohistochemistry Results

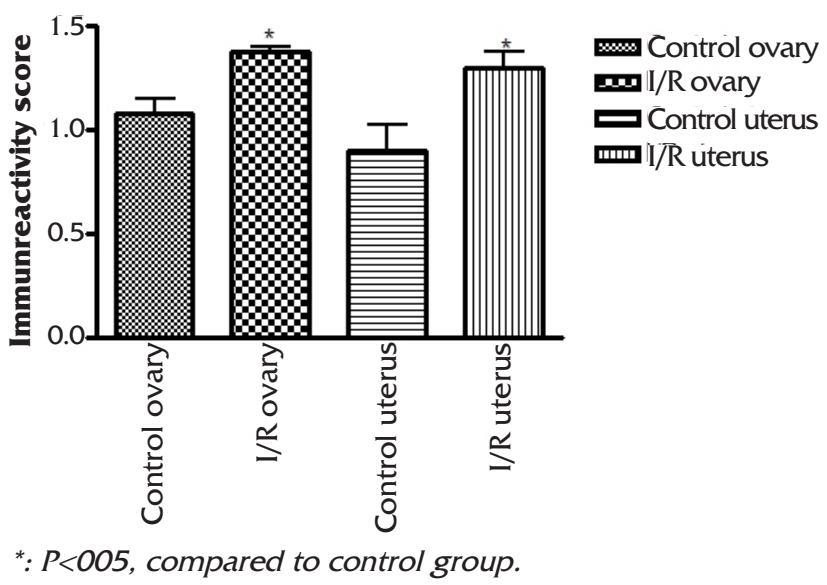

Table 3. HSCORE analysis of VEGF and IL $1 \alpha$ immunreactivity in ovary and uterus.

\begin{tabular}{llll}
\hline & Groups & Ovary & Uterus \\
\hline Control & VEGF & $98 \pm 11.11$ & $85.66 \pm 28.88$ \\
& IL1 $\alpha$ & $98.5 \pm 16.20$ & $61.33 \pm 12.77$ \\
I/R & VEGF & $133 \pm 30.19^{*}$ & $136.6 \pm 16.80^{*}$ \\
& IL1 $\alpha$ & $139 \pm 10.71^{*}$ & $142.8 \pm 6.53^{* *}$ \\
\hline
\end{tabular}

${ }^{*}: p<0.05$ and ${ }^{* *}: p<0.01$ control versus $I / R$

\section{DISCUSSION}

In our study, we showed distribution and alterations in VEGF and IL- $1 \alpha$ in ischemia-reperfused ovary and uterine tissues. VEGF and IL $1 \alpha$-ir were increased in ovary and uterine tissues after ischemia-reperfusion parallel with histopathological degeneration in follicular development and endometrial lining.

VEGF levels are increased to maintain tissue reperfusion via providing angiogenesis during ischemia-reperfusion in several tissues. Early treatment with VEGF also reportedly preserves the vascular structure after $I / R^{12}$. VEGF is downregulated after acute kidney damage, and long-term consequences of that acute kidney damage are decreased microvessel density and impaired renal concentrating ability ${ }^{13}$.
Murayama et al. ${ }^{14}$ showed that IL is related with the VEGF system in theca cells of bovine ovarian tissue. Moreover, VEGF is associated with IL-8 for follicular stage-dependent development. Furthermore, their results showed that the CXCR genes in transcription system might have different pathways for stimulation of VEGF in bovine theca cells.

VEGF is a signal protein which aggravates the rise in permeability of theca blood vessels just before the ovulation. The oocyte of primary follicles is surrounded by granulosa and theca cell layers and fibrous tissue of ovarian stroma. Kamat et al. showed that, this cell layer of normal primary follicles does not histologically stain for VEGF by immunohistochemistry ${ }^{15}$. Granulosa cells are stained first weakly and then strongly for VEGF during the process of Graafian follicle formation and fluid accumulation. Likewise, theca cells are stained faintly. Follicular granulosa cells transform into granulosa lutein cells after ovulation which show intense cytoplasmic staining for VEGF in early corpus luteum. Nonetheless, variable staining is observed in further corpus luteum development, and also in mature corpus luteum of pregnancy. Although less intensely stained than granulosa cells, luteinized follicular theca lutein cells were shown to be stained for VEGF in maturating corpus luteum. Additionally, during the development of corpus luteum and corpus albicans, VEGF aids in angiogenesis and stroma formation ${ }^{16}$.

Our study showed parallel findings with Kamat et al. ${ }^{15}$ about distribution of VEGF-ir. However, we also showed VEGF-ir positivity in granulosa cells of primary follicle. Additionally, VEGF-ir positivity is the eye catching in the germinal epithelium.

Recent research in ovarian tissue have shown the effects of cytokines during ovulation ${ }^{17}$. IL-1 and tumor necrosis factor (TNF)- $\alpha$ which are secreted by active immune cells, are mostly studied cytokines. IL-1b is shown to be involved in the control of ovarian cell differentiation, follicular maturation, 
and also in triggering prostaglandin production in bovine luteal cells.

In our study, we demonstrated IL- $1 \alpha$ immunoreactivity in germinal epithelial cells and walls of the blood vessels and granulosa cells. Moreover, only the theca interna cells of secondary follicle demonstrated IL- $1 \alpha$-ir positivity and IL- $1 \alpha$-ir positivity was not detected in theca externa cells. This finding implies that IL1 also has function in regulation and modulation of ovarian follicular maturation and cell differentiation.

VEGF is an important factor for early angiogenesis during postmenstrual endometrial regeneration in primates and mice ${ }^{18}$. Presence of VEGF is very critical for implantation. Since the interactions between epithelial cells and stroma are critical for the actions of E2 on uterus and mammary gland, it is necessary to identify the exact location of VEGFA expression in the endometrium ${ }^{19,20}$. Establishing the cell type where VEGFA is firstly expressed could help to resolve the controversies in the literature about the expression of VEGFA in uterus $^{21}$.

Our results showed that VEGF was located in endometrial lining, glandular epithelium of the uterus of control rats. Additionally, VEGF-ir was increased in ischemia-reperfused uterus. It was previously shown by Nemoto et al. ${ }^{22}$ that VEGF transcriptional activators are directly mediated by increased ROS production.

Previous data showed that VEGF and Il-1 were increased in several tissues such as liver $^{23}$ cardiocytes $^{24}$ and cerebrum in ischemia-reperfused rats $^{25}$. However,the interelationships and alterations in VEGF and Il-1 have not been shown in ischemia-repefused rat uterus and ovary previously.

According to our study, IL-1alfa immunoreactivity was increased in I-R uterus. Additionally, in our study, IL- $1 \alpha$ immunoreactivity was located espe- cially in stromal and glandular cells. As a consequence, just like VEGF IL- $1 \alpha$ may act as a mediator between stromal and glandular cells.

\section{CONCLUSION}

This is the one of the studies that have showed VEGF and IL-1 immunoreactivity in both uterine and ovarian tissue after ischemia-reperfusion. In conclusion, VEGF and IL-1 are potential markers that display ischemia-reperfusion damage developed in ovary and uterus Our results give information that VEGF and IL-1alfa have potential to modulate and regulate the ovarian cell differentiation and follicular maturation as well as uterine cycle for implantation.

\section{REFERENCES}

1. Aslan M, Erkanli Senturk G, Akkaya H, Sahin S, Yilmaz B. The effect of oxytocin and Kisspeptin-10 in ovary and uterus of ischemia-reperfusion injured rats. Taiwan J Obstet Gynecol. 2017;56:456-62. [CrossRef]

2. Akdemir A, Erbas O, Gode F, et al. Protective effect of oxytocin on ovarian ischemia-reperfusion injury in rats. Peptides. 2014;55:126. [CrossRef]

3. Grace PA. Ischemia-reperfusion injury. $\mathrm{Br} J$ Surg. 1994;81:637. [CrossRef]

4. Kosieradzki M, Rowinski W. Ischemia/reperfusion injury in kidney transplantation: mechanisms and prevention. Transplant. Proc. 2008;40:3277. [CrossRef]

5. Erkanli Senturk G, Erkanli K, Aydin U, et al. The protective effect of oxytocin on ischemia/reperfusion injury in rat urinary bladder. Peptides. 2013;40:82. [CrossRef]

6. Ozyurt H, Ozyurt B, Koca K, Ozgecmen S. Caddeic acid and phenethyl ester (CAPE) protects rat skeletal muscle against ischemia reperfusion induced oxidative stress. Vasc Pharmacol. 2007;47:108. [CrossRef]

7. Margaritescu O, Pirici D, Margaritescu C. VEGF expression in human brain tissue after acute ischemic stroke. Rom J Morphol Embryol. 2011;4:1283.

8. Maharaj ASR, D'Amore PA. Roles for VEGF in adults. Microvasc. Res. 2007;74:100. [CrossRef]

9. Dinarello CA, Interleukin-1 in the pathogenesis and treatment of inflammatory diseases. Blood. 2011;117:3720. [CrossRef]

10. Zhao DM, Shan YH, Li FH, Jiang L, Qu QL. Correlation Between Endometrial Receptivity With Expressions of IL-1 and VEGF in Rats With Polycystic Ovary Syndrome. Eur Rev Med Pharmacol Sci. 2019;23:5575-80.

11. Tanriverdi G, Kaya-Dagistanli F, Ayla S, et al. Resveratrol can prevent $\mathrm{CCl} 4$-induced liver injury by inhibiting Notch signaling pathway. Histol Histopathol. 2016;31:769-84.

12. Leonard EC, Friedrich JL, Basile DP. VEGF-121 preserves renal microvessel structure and ameliorates secondary renal disease following acute kidney injury. Am J Physiol 
Renal Physiol. 2008;295:F1648. [CrossRef]

13. Jeong EK, Jang HJ, Kim SS, et al. Protective effect of polydeoxyribonucleotide against renal ischemia-reperfusion injury in mice. Transplant Proc. 2016;48:1251. [CrossRef]

14. Murayama C, Kaji A, Miyauchi K, Matsui M, Miyamoto A, Shimizu T. Effect of VEGF (vascular endothelial growth factor) on expression of IL-8 (interleukin-8), IL-1 beta and their receptors in bovine theca cells. Cell Biol Int. 2010;8:34:531. [CrossRef]

15. Kamat BR, Brown LF, Manseau EJ, Senger DR, Dvorak HF. Expression of vascular permeability factor/vascular endothelial growth factor by human granulosa and theca lutein cells. Am. J. Patho. 1995;146:157.

16. Rizk B, Aboulghar M, Smitz J and Ron-El R. The role of vascular endothelial growth factor and interleukins in the pathogenesis of severe ovarian hyperstimulation syndrome. Hum Reprod Update. 1997;3:255. [CrossRef]

17. Kol S, Ben-Shlomo I, Ruutiainen $\mathrm{K}$, et al. The midcycle increase in ovarian glucose uptake is associated with enhanced expression of glucose transporter 3. Possible role for interleukin-1, a putative intermediary in the ovulatory process. J Clin Invest. 1997;1(99):2274. [CrossRef]

18. Kawano N, Miyado K, Yoshii N, et al. Absence of CD9 reduces endometrial VEGF secretion and impairs uterine repair after parturition. Sci Rep. 2014;16(4):4701. [CrossRef]

19. Cunha GR, Cooke PS, Kurita T. Role of stromal-epithelial interactions in hormonal responses. Arch Histol Cytol.
2004;67:417. [CrossRef]

20. Chen B, Pan H, Zhu L, Deng Y, Pollard JW. Progesterone inhibits the estrogen-induced phosphoinositide 3-kinase->AKT->GSK-3beta->cyclin D1->pRB pathway to block uterine epithelial cell proliferation. Mol Endocrinol. 2005; 19:1978. [CrossRef]

21. Kazi AA, Molitoris KH and Koos RD. Estrogen rapidly activates the pi3k/akt pathway and hypoxia-inducible factor 1 and induces vascular endothelial growth factor an expression in luminal epithelial cells of the rat uterus. Biol Reprod. 2009;81:378. [CrossRef]

22. Nemoto T, Kawakami S, Yamashita F, Hashida M. Efficient protection by cationized catalase against $\mathrm{H} 2 \mathrm{O} 2$ injury in primary cultured alveolar epithelial cells. J Control Release. 2007;121:74. [CrossRef]

23. Tiriveedhi V, Upadhya GA, Busch RA, et al. Protective role of bortezomib in steatotic liver ischemia/reperfusion injury through abrogation of MMP activation and YKL-40 expression. Transpl Immunol. 2014;30:93. [CrossRef]

24. Wang Z, Yu J, Wu J, et al. Scutellarin protects cardiomyocyte ischemia-reperfusion injury by reducing apoptosis and oxidative stress. Life Sci. 2016;15:157-200. [CrossRef]

25. Zhang Y, Jia X, Yang J, et al. Effects of Shaoyao-Gancao Decoction on Infarcted Cerebral Cortical Neurons: Suppression of the Inflammatory Response following Cerebral Ischemia-Reperfusion in a Rat Model. BioMed Res Int. 2016;1859254:14. [CrossRef] 